Jurnal Pemberdayaan: Publikasi Hasil Pengabdian kepada Masyarakat

Vol. 2, No. 1, April 2018, Hal. 1-6

ISSN: 2088 4559; e-ISSN: XXXX-XXXX

DOI:

\title{
PEMANFAATAN LAHAN UNTUK APOTEK HIDUP DI LINGKUNGAN PEMUKIMAN PADAT, TAHUNAN, UMBULHARJO, YOGYAKARTA
}

\author{
Kurnia Dewi Anggraeny ${ }^{1}$, Rahayu Retno Hapsari ${ }^{2}$ \\ Universitas Ahmad Dahlan, Yogyakarta ${ }^{1,2}$ \\ Email: kurniadewi@law.uad.ac.id ${ }^{1}$
}

\begin{abstract}
ABSTRAK
Pembuatan apotek hidup di lingkungan pemukiman padat perkotaan sudah jarang ditemui dan perlu untuk digalakkan kembali, saslah satunya di Kelurahan Tahunan, Umbulharjo, Yogyakarta. Hal ini didasarkan pada kebutuhan warga setempat dan masih adanya lahan kosong yang dapat dimanfaatkan. Pembuatan apotek hidup di lingkungan pemukiman padat Kelurahan Tahunan ini sebagai salah satu bentuk pemanfaatan lahan yang tersedia sebagai bentuk program aktivitas warga dan dapat memperbaiki tingkat ekonomi. Sebelum ke tahap pembuatan apotek hidup, dilakukan sosialisasi mengenai apotek hidup kepada warga. Metode pelaksanaan program KKN meliputi : pendidikan masyarakat, dan praktik langsung. Dampak dari kegiatan KKN ini adalah : 1) tercipta kesadaran masyarakat tentang pentingnya Apotek Hidup, 2) sosialisasi dan peningkatan pengetahuan masyarakat dalam mengolah lahan kosong untuk menjadi Apotek Hidup, 3) tahap pembuatan Apotek Hidup oleh mahasiswa bersama-sama dengan masyarakat, 4) lingkungan dapat menjadi lebih hijau, segar dan asri.
\end{abstract}

Kata kunci : Pemanfaatan Lahan, Apotek Hidup, Kelurahan Tahunan

\begin{abstract}
Making living pharmacies in urban dense neighborhoods is rarely encountered and needs to be encouraged again, one of them is at the Kelurahan Tahunan, Umbulharjo, Yogyakarta. This is based on the needs of local residents and there is still vacant land that can be utilized. The making of living pharmacies in the neighborhoods of the Annual Kelurahan is one form of land use available as a form of community activity program and can improve the economic level. Before going to the stage of making a living pharmacy, we also had socialization about living pharmacies to residents. The methods for implementing the KKN program include: community education, and direct practice. The impact of these KKN activities are: 1) creating public awareness about the importance of Apotek Hidup, 2) socializing and increasing community knowledge in processing vacant land to become Apotek Hidup, 3) stages of making Pharmacy Life by students together with the community, 4) environment can be more green, fresh and beautiful.
\end{abstract}

Keywords : Land Use, Living Pharmacy, Annual Village

\section{PENDAHULUAN}

Kelurahan Tahunan merupakan salah satu dari tujuh desa dan kelurahan yang terletak di Kecamatan Umbulharjo, Kota Yogyakarta. Adapun berbagai data yang berkaitan dengan kependudukan, seperti : batas wilayah, kondisi keagamaan, kondisi perekonomian, kondisi kesehatan, kondisi pendidikan, pembagian administratif, serta struktur dan program kerja dari 
struktur yang terdapat di Kelurahan Tahunan, Umbulharjo adalah sebagai berikut: 1) Batas wilayah bagian Utara: Kecamatan Gondokusuman. 2) Batas wilayah bagian Timur: Kecamatan Banguntapan, Bantul dan Kecamatan Kotagede. 3) Batas wilayah bagian Selatan: Kecamatan Banguntapan, Bantul. 4) Batas bagian Barat: Kecamatan Banguntapan, Bantul, Kecamatan Mergangsan dan Kecamatan Pakualaman.

Pemanfaatan lahan merupakan sebuah kegiatan memodifikasi yang dilakukan oleh masyarakat untuk memaksimalkan lahan tersebut. Pemanfaatan lahan terdiri dari dua kata dengan makna berbeda, yaitu pemanfaatan dan lahan. Pemanfaatan (menurut KBBI online) berasal dari kata manfaat - (n) proses, cara, perbuatan memanfaatkan, sedangkan lahan (menurut KBBI online) adalah (n) tanah terbuka; tanah garapan. Menurut (FAO dalam Sitorus, 2005: 37) lahan merupakan "suatu daerah di permukaan bumi dengan sifat-sifat tertentu yang meliputi biosfer, atmosfer, tanah, lapisan geologi, hidrologi, populasi tanaman dan hewan serta hasil kegiatan manusia masa lalu dan sekarang, sampai pada tingkat tertentu dengan sifat-sifat tersebut mempunyai pengaruh yang berarti terhadap fungsi lahan oleh manusia pada masa sekarang dan masa yang akan datang."

Ada banyak cara untuk melakukan penghijauan lingkungan, salah satu contoh yang mudah dilakukan yaitu dengan memanfaatkan lahan yang sudah tersedia dan menjadikannya apotek hidup. Apotek hidup adalah pemanfaatan sebagian tanah atau lahan untuk ditanami berbagai jenis tanaman yang berrmanfaat, umumnya adalah tanaman obat-obatan yang bisa digunakan sehari-hari. Manfaat apotek hidup bagi lingkungan salah satunya adalah lingkungan dengan apotek hidup akan cenderung lebih asri, tenang, dan hijau. Oksigen yang dihasilkan dari tanaman di apotek hidup akan membuat udara di sekitar lingkungan menjadi lebih bersih dan segar.

Pada proses pembuatannya, langkah-langkah yang harus dilakukan yaitu: 1) Disiapkan lubang pada tanah yang subur; 2) Bibit ditanam; 3) Apabila sudah tertanam maka ditutup lubang tersebut dengan tanah 4) apotek hidup disiram agar tidak layu; 5) Diusahakan terkena cukup sinar matahari karena hal ini akan berpengaruh pada tanaman dan dihindarkan dari rumput liar yang menganggu.

Tanaman yang ditanam di dalam apotek hidup berupa tanaman obat yang diyakini banyak manfaat dan khasiatnya bagi kesehatan tubuh, misalnya jahe, lengkuas, bawang merah, daun cincau, kumis kucing, lidah buaya, daun dewa, sambiloto, daun saga, dan lain sebagainya. Berbagai macam tanaman tersebut memiliki fungsi dan manfaat yang berbedabeda bagi kesehatan tubuh kita. Bawang merah misalnya, selain bisa menjadi bumbu dapur juga memiliki banyak khasiat, yaitu sebagai salah satu produk yang bisa meningkatkan asi, 
memelihara kesehatan jantung, mengobati masalah pernapasan, membantu melawan penyakit yang dibawa oleh makanan yang tidak higienis, obat yang sangat tepat untuk sembelit, dapat mengobati tuberculosis, dan mengatur tekanan darah.

Manfaat yang lain untuk kebaikan tubuh warga adalah dengan melakukan sebuah aktivitas sehari-hari yang positif. Aktivitas merawat apotek hidup misalnya, dengan memberi pupuk tanaman secara teratur, menyirami tanaman setiap pagi, menyabut rumput liar yang tumbuh di sekitar tanaman, akan menjadikan tubuh untuk melakukan pergerakan sehingga tubuh akan menjadi lebih bugar.

Tidak hanya berupa tanaman obat-obatan, di dalam apotek hidup tersebut terdapat tanaman sayur-sayuran. Contohnya bayam dan tanaman sayur-sayuran maupun bumbu dapur lain yang bisa dimanfaatkan untuk memasak bagi masyarakat yang hidup di sekitar apotek hidup. Tujuannya adalah untuk penghematan uang belanja sehingga dapat menjaga tingkat ekonomi keluarga. Budget kebutuhan sehari-hari dapat diminimalisir oleh para ibu-ibu dengan menggunakan bahan bumbu dapur yang dapat disediakan sendiri melalui apotek hidup di lingkungan masing-masing.

\section{METODE}

Untuk mendapatkan manfaat yang maksimal dari hasil pemanfaatan lahan untuk apotek hidup di Kelurahan Tahunan, maka metode pengabdian yang digunakan yaitu dengan melakukan sosialisasi kepada warga terlebih dahulu, selanjutnya masuk ke tahap pembuatan apotek hidup. Rincian metode pengabdian, Jam Kerja Efektif Mahasiswa (JKEM) tersaji dalam Tabel 1.

Tabel 1. Tabel Metode Pengabdian, kegiatan dan JKEM

\begin{tabular}{|c|c|c|c|}
\hline No. & $\begin{array}{c}\text { Metode } \\
\text { Pengabdian }\end{array}$ & Kegiatan & JKEM \\
\hline 1 & $\begin{array}{c}\text { Sosialisasi } \\
\text { Manfaat dan } \\
\text { Pembuatan } \\
\text { Apotek Hidup }\end{array}$ & $\begin{array}{l}\text { Menyelenggarakan sosialisasi mengenai } \\
\text { manfaat yang bisa didapatkan dari } \\
\text { pengelolaan apotek hidup dan } \\
\text { menjelaskan langkah-langkah } \\
\text { pembuatan apotek hidup di } 6 \text { RT yang } \\
\text { ada di lingkup RW 01, Keluarahan } \\
\text { Tahunan, Umbulharjo }\end{array}$ & $6 \times 100$ menit \\
\hline \multirow{2}{*}{2} & Pembuatan & $\begin{array}{l}\text { Melakukan pembuatan dan penanaman } \\
\text { apotek hidup bersama warga RT } 06\end{array}$ & $1 \times 200$ menit \\
\hline & Apotek Hidup & $\begin{array}{l}\text { Melakukan pembuatan dan penanaman } \\
\text { apotek hidup bersama warga RT } 06\end{array}$ & $1 \times 200$ menit \\
\hline \multicolumn{3}{|c|}{ Total JKEM } & 1000 menit \\
\hline
\end{tabular}




\section{HASIL, PEMBAHASAN, DAN DAMPAK}

Sosialisasi mengenai pemanfaatan dan pembuatan apotek hidup pertama kali dilakukan di lingkungan RT 01, dilanjutkan dengan RT 02, lalu selanjutnya adalah RT 03, RT 04, RT 05 dan yang terakhir RT 06. Pembuatan apotek hidup itu disepakati akan dilakukan di RT 06 karena lahan yang tersedia hanya terdapat di RT 06. Rincian dari kegiatan tersebut dapat dijelaskan sebagai berikut :

\section{Sosialisasi Manfaat dan Pembuatan Apotek Hidup}

Apotek hidup adalah lahan tanah yang dimanfaatkan sebagai tempat menanam berbagai jenis tanaman yang memiliki banyak khasiat, baik tanaman obat maupun tanaman sayursayuran. Sosialisasi mengenai manfaat dan cara pembuatan apotek hidup pertama kali dilakukan di lingkup RT 01 pada tanggal 28 Oktober 2018, persiapannya dimulai satu hari sebelum hari H. Persiapan yang dilakukan berupa pembuatan dan penyebaran undangan, penyiapan materi dan penyiapan tempat untuk melakukan sosialisasi.

Pada acara sosialisasi ini menjelaskan beberapa contoh tanaman yang bisa ditanam di dalam apotek hidup dan bibit tanaman yang mudah ditemui. Antusiasme dari warga cukup tinggi dibuktikan dengan banyak pertanyaan dari warga. Sesi pertanyaan pun dilakukan beberapa kali untuk menjawab pertanyaan dari warga RT 01, RW 06, Kelurahan Tahunan, Umbulharjo.

Pertanyaan-pertanyaan yang muncul banyak terkait tentang pengembangan apotek hidup selanjutnya karena jarangnya apotek hidup yang dapat ditemui di lingkungan perkotaan disebabkan oleh lahan yang tersedia sangat terbatas. Sebagian besar pemukiman di daerah perkotaan merupakan pemukiman padat penduduk. Selama ini, apotek hidup hanya banyak dijumpai di beberapa lingkungan sekolah dan di desa-desa saja.

Sosialisasi selanjutnya dilakukan pada tanggal 30 Oktober 2018 di RT 02, tanggal 2 November 2018 di RT 03, tanggal 3 November 2018 di RT 04, tanggal 4 November 2018 di RT 05 dan pada tanggal 7 November 2018 di RT 06. Proses persiapan dan kegiatannya sama dengan yang dilakukan di RT 01. Persiapan undangan, penyebaran undangan, persiapan tempat, pelaksanaan kegiatan sosialisasi, dan tanya jawab warga.

2. Pembuatan Apotek Hidup

Pembuatan apotek hidup ini disepakati akan dilakukan oleh warga RW 01 pada hari Minggu, 09 Desember 2018. Persiapan untuk pembuatan apotek hidup ini sudah dimulai dari tanggal 03 Desember 2018 karena kami memulai survey untuk tempat pembelian bibit tanaman yang akan ditanam bersama-sama di apotek hidup. Sebelum itu, perlu dipilih jenis 
tanamannya terlebih dahulu yang akan ditanam. Tahapan selanjutnya yaitu membeli bibit, membeli pupuk dan peralatan yang akan digunakan untuk proses perawatan apotek hidup.

Kegiatan pembuatan ini dimulai pukul 07.00 WIB hingga pukul 13.00 WIB. Kegiatan ini terlebih dahulu dimulai dengan pembersihan lahan yang akan digunakan sebagai tempat apotek hidup. Lahan yang akan digunakan harus mempunyai struktur sebagai tanah subur dan dapat dipertahankan sebagai tempat untuk apotek hidup.

Lahan yang telah dibersihkan dan ditata dengan mengikuti instruksi dari Pak RW, kegiatan selanjutnya adalah untuk membersihan lahan dari rumput liar. Pembersihan dari rumput liar ini ditujukan untuk memberikan lahan yang lebih luas bagi tanaman apotek hidup juga mengurangi kemungkinan terhambatnya pertumbuhan tanaman apotek hidup yang mungkin saja disebabkan oleh tumbuhan liar.

Tahapan selanjutnya adalah pembuatan lubang-lubang yang akan menjadi tempat bibit tanaman apotek hidup. Warga masyarakat yang bekerja sama melubangi tanah dan memasukkan bibit berbagai macam tanaman yang sudah disiapkan. Adapun tanah untuk menutupinya kami dapatkan dari warga sekitar yang memiliki pekarangan dengan berbagai jenis pohon yang mana memiliki tanah yang subur sehingga kami harus bolak balik dengan ember penuh yang berisi tanah.

Gambaran kerja sama proses pembuatan apotek hidup dan aktivitas mahasiswa KKN UAD bersama masyarakat Tahunan, Umbulharjo, terlihat pada Gambar 1.

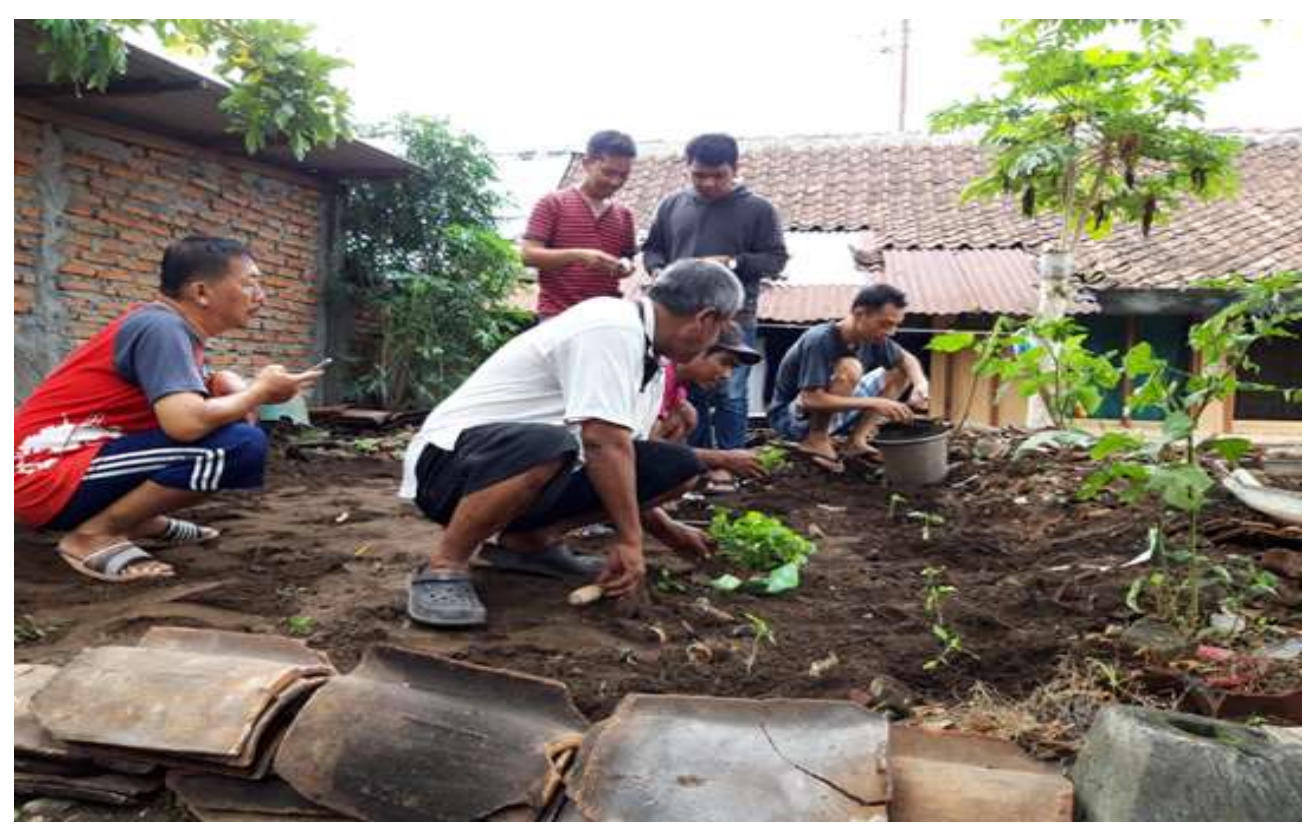




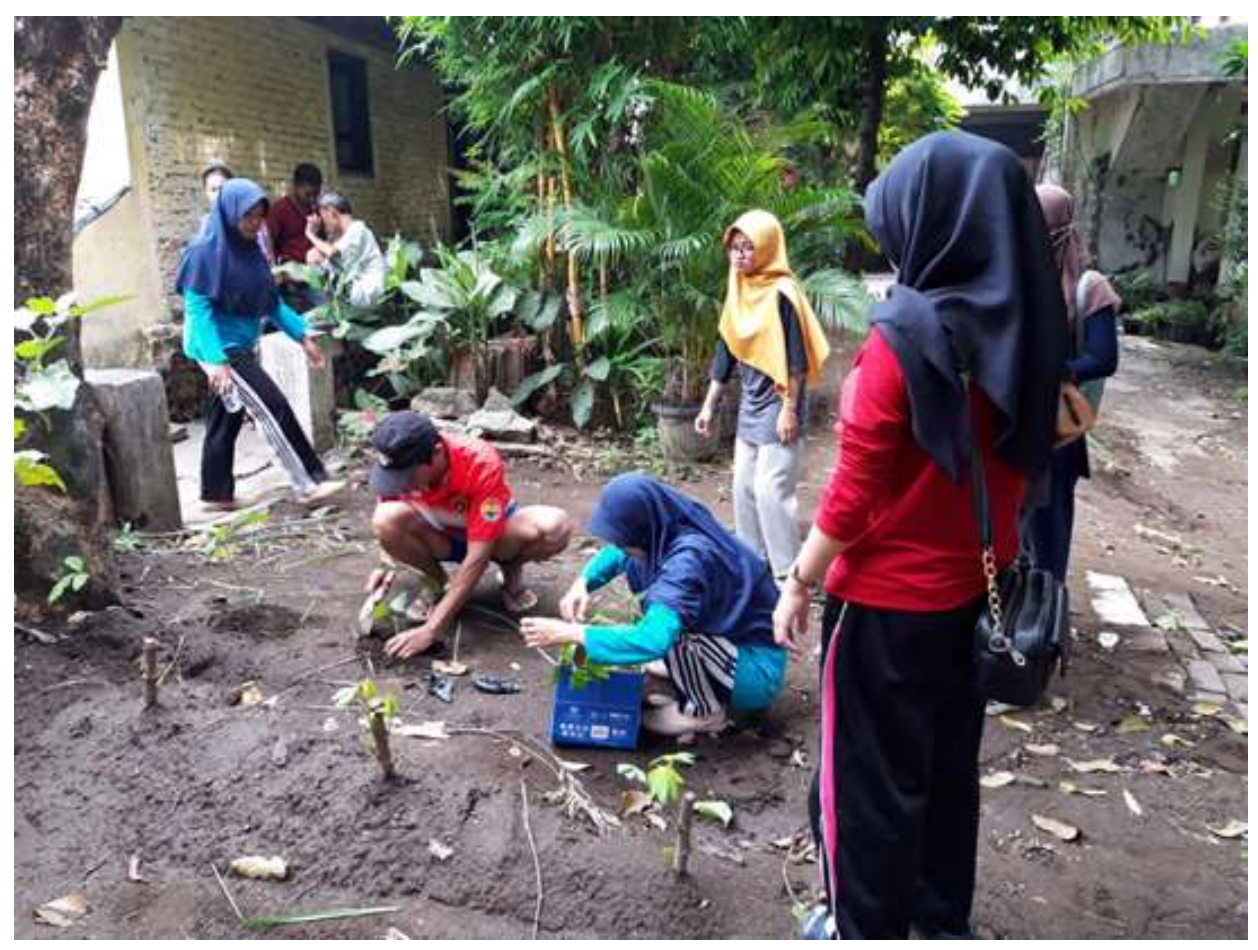

Gambar 1. Proses Pembuatan Apotek Hidup

\section{SIMPULAN}

Metode pelatihan yang diterapkan adalah dengan terlebih dahulu memberikan teori dan dilanjutkan dengan praktik. Dari kegiatan-kegiatan tersebut dampak yang didapatkan yakni warga Kelurahan Tahunan mendapatkan pengetahuan bagaimana memanfaatkan lahan yang ada menjadi apotek hidup yang memiliki banyak sekali manfaat. Dari hasil pelatihan yang diselenggarakan, warga Kelurahan Tahunan Umbulharjo dapat mempraktikkan sendiri apa yang telah disampaikan dan dipelajari di kemudian hari

\section{DAFTAR PUSTAKA}

Sitorus O. 2005. Pemberian Hak Atas Tanah yang Berwawasan Lingkungan. Bhumi Nomor 17 Tahun 6, Februari 2005. Yogyakarta: STPN. 